IRSTI 82.15.09

\author{
Dalcher D. ${ }^{1}$, Tsekhovoy A. ${ }^{2}$, Akzambekkyzy A. ${ }^{3}$ \\ ${ }^{1} \mathrm{PhD}$ Doctor, Lancaster University, United Kingdom, Lancaster, \\ e-mail: ddalcher@lancaster.ac.uk \\ ${ }^{2}$ Professor-Doctor, e-mail: tsaf@list.ru \\ ${ }^{3}$ Doctoral student, e-mail: akzambekkyzy@mail.ru \\ 2,3al-Farabi Kazakh National University, Almaty, Kazakhstan
}

\title{
PROJECT MANAGEMENT SYSTEM: \\ ENVIRONMENTAL FACTORS AND ASSETS OF DEVELOPMENT PROCESSES
}

\begin{abstract}
In this study the information was given about environmental factors and assets of development processes for creating a project management system in accordance with the state system of technical regulation. Operational activities that cover $80 \%$ of the activities of all organizations are standardized in accordance with ISO 9000, ISO 9001, ISO 14001, ISO 50001, ISO 31000, ISO 27001, etc. The remaining $20 \%$-- project activity in Kazakhstan is not systematized. The purpose of this study is to identify the readiness of the market in Kazakhstan to create a project management system. In-depth study of the market using the methods of trend analysis and expert assessment of the situation in Kazakhstan was able to get results on eight major environmental factors and assets of the development processes of the project management system in Kazakhstan. As a result of the research, it was revealed that all the basis for the creation of this system is ready. The project management system in Kazakhstan can be part of the overall enterprise management system, which should ensure the effective achievement of the objectives of the projects, programs and portfolios of the organization to ensure effective organizational development of enterprises.
\end{abstract}

Key words: project management system, standardization, environmental factors, assets of development processes.

\author{
Аалкер А. ${ }^{1}$, Цеховой А. ${ }^{2}$, Акзамбекқызы А. ${ }^{3}$ \\ 'PhD доктор, Аанкастер Университеті, Ұлыбритания, Аанкастер қ., \\ e-mail: ddalcher@lancaster.ac.uk \\ ${ }^{2}$ Аоктор-профессор, e-mail: tsaf@list.ru \\ ${ }^{3}$ Аокторант, e-mail: akzambekkyzy@mail.ru \\ 2,3 әл-Фараби атындағы Қазақ ұлттық университеті, Қазақстан, Алматы қ. \\ Жобалау менеджментінің жүйесі: \\ орта факторлары мен даму үрдістерінің активі
}

Бұл зерттеу жұмысында мемлекеттік техникалық реттеу жүйесіне сәйкес жобалау менеджменті жүйесін құруға қажетті орта факторлары мен даму үрдістерінің активтері тура^ы мәліметтер көрсетілген. Барлық ұйымдардың 80 \% қызметін құраушы операционды қызмет ISO 9000, ISO 9001, ISO 14001, ISO 50001, ISO 31000, ISO 27001 және т.б. стандарттар бойынша реттеліп, жүйеленген. А^ қалған 20 \%-дық жобалау қызметі Қазақстан ұйымдарында мемлекеттік техникалық реттеу жүйесіне сәйкес стандартпен жүйеленбеген. Аталған зерттеудің басты мақсаты Қазақстан нарығының жобалау менеджменті жүйесін құруға дайындығын анықтап, дайындық Аеңгейін көрсету. Қазақстанның жобалау менеджментіне қатысты нарығын тенденциялық та^дау және экспертті бағалау әдістерінің көмегімен зерттеу арқылы негіз құрушы сегіз түрлі орта факторлары мен даму үрдістерінің активтері жайлы нәтижелер алуға мүмкіндік болды. Зерттеу нәтижесінде Қазақстан Республикасында жобалау менеджменті жүйесін құруға қажетті барлық негізгі факторлар бар екендігі анықталып, олардың нақты сипаттамасы берілді. Қазақстанда 
жобалау менеджменті жүйесі ұйымды басқарудың жалпы жүйесімен интеграцияланып, ұйым жобаларының, бағдарламаларының және портфелінің мақсаттарына тиімді жетуге көмек беріп, ұйымдардың жүйелі дамуына негіз болады.

Түйін сөздер: жобалау менеджменті жүйесі, стандартизациялау, орта факторлары, даму үрдістерінің активтері.

\author{
Аалкер $\Delta .{ }^{1}$, Цеховой А. ${ }^{2}$, Акзамбеккызы А. ${ }^{3}$ \\ 'PhD доктор, Университет Аанкастер, Великобритания, г. Аанкастер, \\ e-mail: ddalcher@lancaster.ac.uk \\ ${ }^{2}$ Аоктор-профессор, e-mail: tsaf@list.ru \\ ${ }^{3}$ Аокторант, e-mail: akzambekkyzy@mail.ru \\ 2,3 Казахский национальный университет имени аль-Фараби, Казахстан, г. Алматы \\ Система проектного менеджмента: \\ факторы среды и активы процессов развития
}

\begin{abstract}
В данном исследовании представлены сведения о факторах среды и активах процессов развития Аля создания системы проектного менеджмента в соответствии с государственной системой технического регулирования. Операционная деятельность, которая охватывает $80 \%$ Аеятельности всех организаций, стандартизирована согласно стандартам ISO 9000, ISO 9001, ISO 14001, ISO 50001, ISO 31000, ISO 27001 и др. Оставшаяся 20 \%-ная проектная деятельность организаций в Казахстане не систематизирована. Целью Аанного исследования является выявление готовности рынка Казахстана для создания системы проектного менеджмента. Глубокое изучение рынка проводилось с помощью методов анализа тенденций и экспертной оценки ситуации в Казахстане, удалось получить результаты по восьми основным факторам среды и активам процессов развития системы проектного менеджмента в Казахстане. В результате исследования было выявлено, что все основополагающие факторы для создания данной системы готовы. Система проектного менеджмента в Казахстане может быть интегрированной частью общей системы управления развитием предприятия, которая Аолжна обеспечить эффективное Аостижение целей проектов, программ и портфелей организации А^я обеспечения эффективного организационного развития предприятий.
\end{abstract}

Ключевые слова: система проектного менеджмента, стандартизация, факторы среды, активы процессов развития.

\section{Introduction}

Project management is currently entrenched as a phenomenon. It received absolute recognition as a technology that, unlike process, functional management, allows achieving goals in the face of constraints and a high degree of uncertainty by a detailed plan, minimizing risks and deviations from the plan, and effective change management. A key factor in the success of project management is ensuring transparent project implementation, and this indicates a significant anti-corruption potential of the technology (Charbonneau Commission, 2014:3).

According to a research of professional association in the sphere of project management in Kazakhstan, in a business environment there are requests for certification of the companies on a control system of projects how the organizations are certified on a quality management system (UPMRK, 2018). Passing of such certification by the organization is the evidence of introduction of the standard of project management by it in the activity that answers a modern trend of development of design management in the world (Padalkar and Gopinath, 2016: 1308)

Fast rates of development of project management in the country demand also systematization, in compliance and with other systems of management, and there is no such system in the Republic of Kazakhstan. The system of project management in Kazakhstan can be a part of the general enterprise management system, which has to provide effective achievement of the goals of projects, programs and portfolios of the organization for ensuring effective organizational development of the enterprises.

In organizations, according to the standard distribution, there are two types of activity: operating $(80 \%)$ and project $(20 \%)\left(\right.$ PMBOK $^{\circledR}$ Guide, 2018:10). Operational activity, which covers $80 \%$ of the activities of all organizations, is standardized according to ISO 9000, ISO 9001, ISO 14001, ISO 50001, ISO 31000 , ISO 27001, etc. The system of certification of companies in the areas of standardization established in our state is also built for them. The remaining $20 \%$ is a project activity 
that ensures rapid growth for companies that are not systematized, and it requires in-depth research.

The operational and project activities of the organization, respectively, both the quality management system and the project management system should work in integration with each other, only then the organizational development of the company and the improvement of the quality of their services and goods will be ensured.

\section{Literature Review}

Project management gives tangible results in all areas of application, including reducing corruption risks in the management of government programs and projects. This explains its international popularity as an innovative management technology. Projectoriented management technology has provided advanced countries with dynamic development and higher competitiveness. Today this culture of management is recognized as a kind of professional bridge in the business cooperation of countries from different continents and in the civilization business.

Environmental factors and assets of development processes are the basis for the creation of a project, program and portfolio that give rise to the creation of a new product, result or service (Mairaj and Ahsan, 2015: 5296).

To create a project management system, it is necessary to study what environmental factors and assets of development processes are there to create this system.

The main question of the research is whether there are factors and assets of processes for creating this project management system, which will be similar to the quality management system. The project management system is a state technical regulation of project activities in the Republic of Kazakhstan. That is, it be aimed at improving the efficiency of the project activities of organizations.

Estimated project management system identical to the ISO 9001 quality management system is expected to increase the efficiency of project activities of companies in the Republic of Kazakhstan.

Project management based on the elements of detailed planning, team building, time management, risk management, change management, significantly increases the efficiency of implementation of government programs and projects (Lisa and Beth, 2002:21)

Educational programs in project management have grown rapidly during the last three decades to support the need for competence (Atkinson 2006;
Umpleby and Anbari, 2004: 185). The number of academic project management programs leading to degrees in project management increased greatly from 1990 onwards. This growth is evident in the US, Europe, Australia, Japan and other parts of the world (Turner and Anbari, 2013: 4).

The role of project management in the formation of national innovation systems is great. World practice shows that the creation of national innovation systems of leading economies of the world has always been preceded by the adoption of national project management standards (Yamei, 2013:533).

\section{Materials and methods}

The main stages of the study: determining considerations for system startup; determination of environmental factors; identification of developmental assets.

Applied methods of expert evaluation, benchmarking and trend analysis.

System can be authorized as a result of the following strategic considerations: market demand; strategic opportunity/business need; social need; environmental consideration; customer request; legal requirement $\left(\mathrm{PMBOK}^{\circledR}\right.$ Guide, 2018:10).

The factors that may influence the creation of this system are as follows:

- increased demand for specialists in project management in the market, which can be determined using wage statistics;

- professional associations for project management in the country;

- academic training of graduates;

- government employees trained in project management;

- functioning project offices in large structures of fields of activity;

- national project management standards;

- certified project management specialists;

- various activities to promote the culture of project management in the country.

When considering environmental factors, it is necessary to study the experience of foreign countries. According to world experts, more than 24.4 million professionals worldwide are involved in project-oriented activities to implement changes in various areas of creating new products and services.

In many countries of the world where project management is applied, wage statistics of project managers is maintained, as this determines the market demand for owners of this profession (LaPrad, 2019: 12). 
The countries where project management professionals report the highest median salaries are Switzerland (US\$130,996), the United States (US\$112,000), and Australia (US\$108,593), whereas the country with the lowest median salary is Egypt (US\$10,159) (Salary Survey 10th Edition, 2018: 11).

About $\$ 10$ trillion a year of global funds is spent on project management. Practice shows that the use of standard project technologies in large projects gives an economic effect of $15-20 \%$. Therefore, by the end of 2020 , about $30 \%$ of the world budget or $\$ 45$ trillion will be allocated to programs and projects (Wedekind and Philbin, Patrick, 2018: 44).

Due to its advantages, project management is widely used in business, government and society, both in the framework of the activities of a single company or organization, and in all areas of the economy.

The task of entering Kazakhstan among the 30 competitive countries of the world against the background of the current time challenges actualizes the need to accelerate the pace of institutionalization of project management in the country and the implementation of this progressive tool in all spheres of state activity.

In Kazakhstan, there are a number of factors that influence the creation of a project management system. One of the important factors is the presence of professional associations in the country.

In 2003, the Kazakhstan Project Management Association and the Union of Project Managers of the Republic of Kazakhstan were created. Both organizations see their main task in the development of project management practices in Kazakhstan.

Professional associations initiated the opening in Kazakhstan of academic training in the specialty «project management» in the magistracy and doctoral studies. Today, such training is conducted in five universities of Kazakhstan. To date, about 250 masters and $7 \mathrm{PhD}$ doctors in this specialty have been trained.

This allowed in the second decade of the 21st century bringing the significance of project management to the state level. The Kazakhstan portfolio of support for innovation and entrepreneurship development included tools and measures that encourage businesses to use this technology. They have been present since 2012 in the state program «Productivity 2020» and from 2015 in the Unified program of support and development of business «Business Road Map 2020» (Business Road Map, 2020: 2).
In 2011, the Kazakhstan Institute for the Development of Industry has been operating the Project Office for the Management of State Projects Included in the Map industrialization of the country.

In 2012, in Satbayev University created the International Center for Project Management, which coordinates the development of training programs for the training of economic and technical specialists, ensuring that these programs comply with the requirements of the Project Management Institute - Project Management Institute, USA.

Since 2013, a project management department has been functioning in the Kazakhstan Center for Public-Private Partnership, whose task is analytical research in this area.

Kazakhstan is gaining momentum in the tendency to learn the design practices of civil servants. For this purpose, the Project Management Center of the Academy of Public Administration under the President of the Republic of Kazakhstan was established, which is aimed at developing appropriate training programs and introducing them into the training practice. This is a very large and large-scale work that the Academy began with the support of the project of the European Council, the Regional hub in the sphere of civil service, the World Bank, the Tony Blair Associates group.

The academy began to train civil servants in project management in November 2014, systematically addressing this issue. First, a group of specialists from the Project Management Center was trained. 7 training seminars, including 4 - with the participation of international experts, as well as special advanced training courses for teachers (Training of Trainers) in one of the leading centers in the UK. At the expense of the funds and with the support of the European Union project, 7 members of the Center successfully passed the international certification exam according to the British standard PRINCE-2 (APA, 2014: 12).

To date, the Project Management Center has entered into Memorandums of Cooperation with the Project Management Association «SOVNET» (Russia), Kazakhstan Center for PPP JSC; established contacts on cooperation in the implementation of project management principles in the public administration system with the World Bank; Tony Blair Associates (TBA), EU Project «Regional Development of Kazakhstan», the Union of Project Managers of the Republic of Kazakhstan, etc.

In November 2014, at the initiative and with the direct participation of SPM RK, was developed the national standard ST RK ISO 21500-2014 - 
Guidelines for project management, which came into force on January 1, 2016. The Committee for Technical Regulation and Metrology of the Ministry of Investment and Development of the Republic of Kazakhstan intends to continue to work on expanding the range of standards for the project management series (KazInSC, 2015:16).

State development institutions contribute to the development of project management in Kazakhstan. In 2013 and 2014, the Kazakhstan Institute of Standardization and Certification of the Committee for Technical Regulation and Metrology organized a series of regional seminars on the theme «Implementation of quality management systems in domestic enterprises» in eight cities.

In May 2014, at the request of «Damu» Entrepreneurship Development Fund, UPM RK developed a training manual «Project Management as a Tool for Company Development» for existing entrepreneurs. Within the framework of the project «Business Advisor-2» of the state program «Business Road Map 2020» under this manual, the Fund organized in July-December 2014 in all regions of the country training in project management of 3 thousand small and medium-sized entrepreneur, consolidating efforts for this purpose leading training structures (Business Advisor-2, 2015: 15)

\section{Results and discussion}

Quite actively, project management is being implemented in large national, foreign and international companies operating in our country. Project management objectives are linked to the current processes of companies, organizational structures, and their development strategies. An increasing number of companies are becoming project-oriented, are engaged in the professional development of their specialists, implement corporate systems and open project management offices.

The management of projects requires a special type of organization to administer project resources in an effective manner and maintain clear accountability for the progress of the project (Holstein and McLeod, 2013: 12).

In accordance with the growing demand, the network of organizations conducting short-term training of specialists at seminars is expanding. Table 1 presents in particular, that only SPM RK has trained more than 8 thousand people in project management. Taking into account the contribution to the educational process of other similar structures, this figure reaches 15 thousand.

As seen in Table 1, project management experts are in different areas of Kazakhstan's activities. The greatest number of specialists is in national companies and the mining and metallurgical sector. Trend analysis shows an annual increase in specialists, up to $20 \%$ annually.

As a result, these specialists, according to the development model of the members of the Tuckman Ladder project team, have been formed, are now improving their skills and asserting them through certification.

Table 1 - The trained experts in different structures of fields of activity of Kazakhstan

\begin{tabular}{|c|c|c|c|c|c|c|}
\hline Fields of activity & 2003-2010 & $2011-2015$ & 2016 & 2017 & 2018 & Total \\
\hline 1. Government structures & 571 & 779 & 379 & 477 & 604 & 2810 \\
\hline $\begin{array}{l}1.2 \text { Office of the Prime Minister, Government of } \\
\text { the Republic of Kazakhstan, Ministries, Agencies, } \\
\text { committees and akimats }\end{array}$ & 231 & 92 & 8 & 35 & 2 & 368 \\
\hline $\begin{array}{l}\text { 1.3 Senate and Mazhilis of the Parliament of the } \\
\text { Republic of Kazakhstan }\end{array}$ & 0 & 2 & & & & 2 \\
\hline 1.4 Development institutes and national companies & 300 & 665 & 347 & 440 & 602 & 2354 \\
\hline 1.5 Others in this sector & 40 & 20 & 24 & 2 & & 86 \\
\hline 2. Civil Society Institutions & 29 & 62 & 1 & 93 & 105 & 290 \\
\hline 2.1 Professional associations & 18 & 31 & 1 & 93 & 105 & 248 \\
\hline 2.2 Political parties & 11 & 31 & & & & 42 \\
\hline 3. International organizations, funds, embassies & 19 & 39 & 1 & & & 59 \\
\hline 3.1 International organizations, funds, embassies & 19 & 32 & 1 & & 1 & 59 \\
\hline 4. Structures by branches of the economy & 864 & 1985 & 353 & 645 & 1444 & 5291 \\
\hline 4.1 Agrarian sector & 10 & 56 & 5 & 11 & 10 & 92 \\
\hline
\end{tabular}


Dalcher D. et al.

Continuation of table 1

\begin{tabular}{|c|c|c|c|c|c|c|}
\hline Fields of activity & $2003-2010$ & $2011-2015$ & 2016 & 2017 & 2018 & Total \\
\hline 4.2 Mineral Resources Sector & 16 & 74 & 1 & 10 & 15 & 116 \\
\hline 4.2.1 Mining and Metallurgical Complex & 70 & 282 & 29 & 187 & 305 & 873 \\
\hline 4.2.2 Oil and gas complex & 35 & 91 & 6 & 24 & 42 & 198 \\
\hline 4.2.3 Others in this sector & 15 & 20 & 15 & 17 & 11 & 78 \\
\hline 4.3 Industrial Sector & 0 & 1 & 21 & 10 & 13 & 32 \\
\hline 4.3.1 Petrochemical and oil and gas industry & 14 & 61 & 59 & 25 & 152 & 301 \\
\hline 4.3.2 Engineering & 0 & 18 & 0 & 2 & 8 & 28 \\
\hline 4.3.3 Light industry & 15 & 23 & 6 & 1 & 11 & 56 \\
\hline 4.3.5 Others in this sector & 2 & 20 & 1 & 18 & 1 & 42 \\
\hline 4.4 Energy sector & 9 & 44 & 7 & 7 & 121 & 188 \\
\hline 4.5 Transport, communications & 122 & 223 & 61 & 133 & 143 & 682 \\
\hline 4.6 Construction sector & 94 & 189 & 18 & 97 & 195 & 593 \\
\hline 4.7 IT- sector & 179 & 407 & 37 & 16 & 42 & 681 \\
\hline 4.8 Credit and financial sector & 156 & 211 & 45 & 48 & 109 & 611 \\
\hline 4.9 Service sector & 33 & 9 & 26 & 9 & 103 & 179 \\
\hline 4.9.1 Training and Consulting Companies & 72 & 85 & 16 & 21 & 19 & 213 \\
\hline 4.9.4 Others & 44 & 170 & 0 & 8 & 1 & 277 \\
\hline 4.3.4 Food industry & 2 & 1 & & 1 & 101 & 103 \\
\hline 5. Social sphere & 90 & 276 & 136 & 26 & 9 & 537 \\
\hline 5.1 Education, science and culture & 90 & 275 & 136 & 21 & 6 & 528 \\
\hline 5.2 Health care & 0 & & & 5 & 3 & 1 \\
\hline 6. Mass media & 1 & & 6 & 10 & 13 & 30 \\
\hline 6.1 Print mass-media & 1 & & 6 & 10 & 10 & 27 \\
\hline 6.2 Electronic media & & & & & 3 & 3 \\
\hline TOTAL & 1574 & 3082 & 876 & 1251 & 2175 & 8958 \\
\hline
\end{tabular}

According to the data as of January 10, 2019, there are 174 Project Management Professional Certificate credential holders in Kazakhstan. Table 2 shows the growth trend of PMP specialists for 2012 to 2018. According to the analysis of the annual growth of specialists on average by $12 \%$.

In accordance with the national standard for certification of project managers in Kazakhstan, the NCB defined in 2007, built based on the international standard ICB of the international project management association IPMA in Kazakhstan, has more than 3,000 certified at various levels $(\mathrm{A}, \mathrm{B}, \mathrm{C}, \mathrm{D})$ project management specialists (KPMA, 2018:13).

Institutionalization of project management in Kazakhstan is also facilitated by specialized events organized by the structures of the project community. Since 2002, several international project management symposia have been held in the republic. In 2009 and
2012, two International Forums «Project Management in Central Asia» took place, the initiator and organizer of which was the Union of Project Managers of the Republic of Kazakhstan.

In April 2015, the Academy of Public Administration under the President of the Republic of Kazakhstan organized a Round Table on the theme «Implementation of the principles of project management in the state bodies of the Republic of Kazakhstan based on international standards» inviting representatives of state structures.

The Academy of Public Administration, together with the Kazakhstani PPP Center and the Union of Project Managers of the Republic of Kazakhstan, on November 27, 2015, held the I International Congress of Project Managers on the theme: «Development of Project Management: Practice and Prospects». 


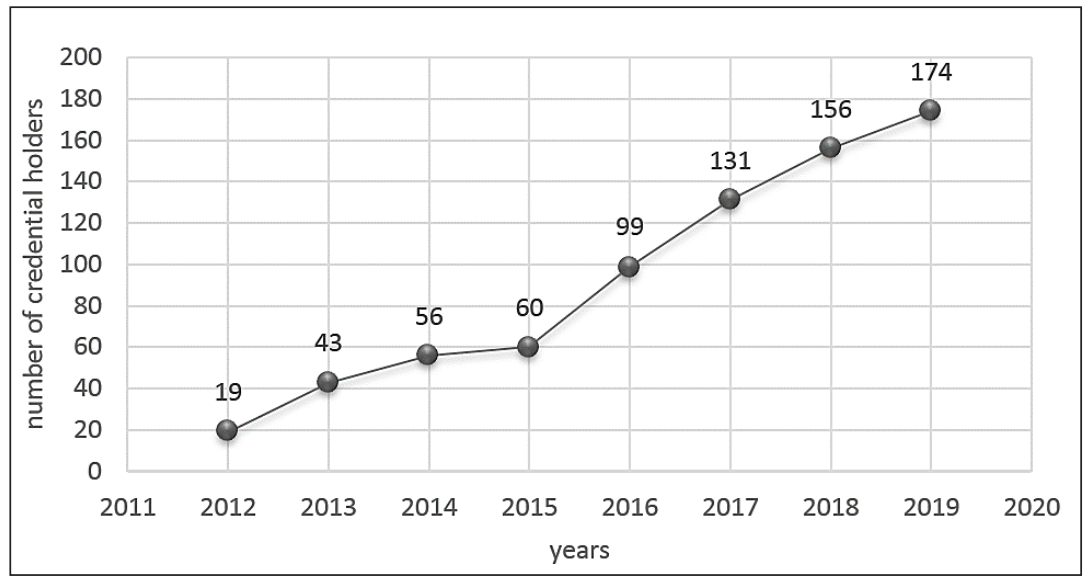

Figure 1 - Growth of number of PMP certified specialists in Kazakhstan Note - compiled by the authors on the basis of the source UPMRK, 2018

In the framework of the Congress were discussed topical issues of development and implementation of project management principles in the activities of the state, quasi-state and business sectors of the Republic of Kazakhstan, international experience in using project management tools. But in general, the development of project management in Kazakhstan is haphazard.

According to the reports of the Accounts Committee on the execution of the republican budget, there is a lack of interconnection between strategic and budget planning; in the management of government programs and projects, the relevant standards are not applied. As a result, government programs and projects much more often than private sector projects do not achieve the planned results in the proper amount (Mark et al., 2006: 639).

On the initiative and with the active participation of professional association, standard «National standard ST RK ISO 21500-2014 - Guidelines on project management» was harmonized in Kazakhstan in 2014. Table 3 shows the analysis of existing and planned standards in Kazakhstan.

Table 2 - Current and planned standards in Kazakhstan

\begin{tabular}{|l|c|c|c|}
\hline Standards & Status & Date of adoption & Date of entry \\
\hline ST RK ISO 21500-2014 - Guidelines on project management & Published & $\begin{array}{c}\text { November } \\
2014\end{array}$ & $\begin{array}{c}1 \text { January } \\
2016\end{array}$ \\
\hline $\begin{array}{l}\text { ST RK 2831-2016 - Project Management. Project } \\
\text { Management Requirements }\end{array}$ & Published & $\begin{array}{c}18 \text { November } \\
2016\end{array}$ & $\begin{array}{c}1 \text { January } \\
2018\end{array}$ \\
\hline $\begin{array}{l}\text { ST RK ISO 21504-2016- } \\
\text { Project Management. Project, program and portfolio } \\
\text { management. Guidelines on Portfolio Management }\end{array}$ & Published & $\begin{array}{c}18 \text { November } \\
2016\end{array}$ & $\begin{array}{c}1 \text { January } \\
2018\end{array}$ \\
\hline $\begin{array}{l}\text { ST RK ISO 21505 - Project, programme and portfolio } \\
\text { management -Guidance on governance }\end{array}$ & Published & $\begin{array}{c}\text { November } \\
2018\end{array}$ & 1 January \\
2020
\end{tabular}


Continuation of table 1

\begin{tabular}{|l|c|c|c|}
\hline Standards & Status & Date of adoption & Date of entry \\
\hline $\begin{array}{l}\text { ISO/AWI 21502 Project, Programme and Portfolio } \\
\text { Management - Guidance on Project Management }\end{array}$ & $\begin{array}{c}\text { International Standard } \\
\text { under publication }\end{array}$ & 2020 & 2022 \\
\hline $\begin{array}{l}\text { ISO/PRF TR 21506 Vocabulary for Project, Programme and } \\
\text { Portfolio Management }\end{array}$ & $\begin{array}{c}\text { International Standard } \\
\text { under publication }\end{array}$ & 2020 & 2022 \\
\hline Note - compiled by authors on the basis of the source KazInSC, 2015 & \\
\hline
\end{tabular}

The range of existing national standards can positively influence the development of the project management system in the country. In addition, the state system of technical regulation of project activities will be based on the standard ST RK 28312016 - Project Management. Project Management Requirements.

Eight types of factors and assets of processes exist in Kazakhstan, which can provide a basis for creating a project management system in accordance with the system of state technical regulation of project activities in the Republic of Kazakhstan. There are as follows: increased demand for specialists in project management in the market; professional associations for project management in the country; academic training of graduates; government employees trained in project management; functioning project offices in large structures of fields of activity; national project management standards; certified project management specialists; various activities to promote the culture of project management in the country.

\section{Conclusion}

The main factors that may affect the creation of project management system were reviewed and identified. All based eight factors and assets of development processes in Kazakhstan exist and show a tendency to further growth and development. The project management system in Kazakhstan can be part of the overall enterprise management system, which should ensure the effective achievement of the objectives of the projects, programs and portfolios of the organization to ensure effective organizational development of enterprises. Creating a project management system identical to the ISO 9001 quality management system is expected to increase the efficiency of the project activities of RK companies.

According to the results of the study, can be conclude that Kazakhstan has all the prerequisites for creating a project management system that will undoubtedly give impetus to the rapid growth of organizations and the improvement of the quality of their goods and services.

\section{References}

Annual report (2018) The Union of project managers, PMI R.E.P 2458. Almaty, p. 26.

Annual report (2014) Academy of Public Administration under the President of the Republic of Kazakhstan. Astana, p. 30.

Annual report (2015) Kazakhstan Institute of Standardization And Certification. Astana, p. 30.

Annual report (2018) Kazakhstan Project Management Association. Almaty, p. 12.

Atkinson R. (2006) Guest editorial: Excellence in teaching and learning for project management. International Journal of Project Management, vol. 24, pp. 185-186.

Business road map-2020 (2008) Available at: https://www.damu.kz/en/dorozhnaya-karta-biznesa-2020 (accessed 10.01.2019)

Business Advisor-2 (2015) Available at: https://damu.kz/dorozhnaya-karta-biznesa-2020/proekt-biznes-covetnik.php (accessed 10.01.2019)

Charbonneau Commission (2014) Golden rules of project management in the fight against corruption. Montreal, PMI-Montreal Chapter, p 3.

LaPrad L. (2019) How Much Do Project Managers Make? TeamGantt, vol. 5/2, p. 12.

Mairaj A., Ahsan A. (2015) External enterprise environment factors negatively influencing software project management. The Science International (Lahore), vol. 28/6, pp. 5295-5299.

Padalkar M., Gopinath S. (2016) Six decades of project management research: Thematic trends and future opportunities. International Journal of Project Management, vol. 34/7, pp. 1305-1321.

Project Management Institute (2018) A guide to the project management body of knowledge (PMBOK guide). Newtown Square, Pa: Project Management Institute, p. 18. 
Pyne L.S., Rigby B. (2002) Implementing a project management culture in a government organization. Paper presented at Project Management Institute Annual Seminars \& Symposium, San Antonio, TX. Newtown Square, PA: Project Management Institute, p. 22.

Project Management Institute (PMI) (2018) Earning Power: Project Management Salary Survey 10th Edition. Salary data based on survey responses from 10,937 U.S. project management practitioners, p. 26.

Turner R., Anbari F. (2013) Perspectives on research in project management: the nine schools. Global Business Perspectives. vol. $1 / 1$, pp. 3-28.

Wedekind G.K., Philbin S.P. (2018) Research and Grant Management: The Role of the Project Management Office (PMO) in a European Research Consortium Context. Journal of Research Administration, vol. 49/1, pp. 43-62.

William K.H., Thomas S.M. (2013) The Management of Research and Development Activities. Britannica encyclopedia, pp. 12. Available at: https://www.britannica.com/topic/research-and-development/Introduction (accessed 4.01.2019)

Winter M., Smith C., Morris P., Cicmil S. (2006) Directions for future research in project management: The main findings of a UK government-funded research network. International Journal of Project Management, vol. 24/8, pp. 638-649.

Yamei G. (2013) Research of innovation system about project management audit. Innovation Management and Industrial Engineering, Xi'an, China, DOI: 10.1109/ICIII.2013.6703600, pp. 532-535. 